\title{
STUDI HADIS TEMATIK
}

\author{
Maulana Ira \\ Mahasiswa Magister Program Studi Hukum Ekonomi Syariah, \\ Program Pascasarjana Institut Agama Islam Negeri Langsa \\ Kampus Zawiyah Cot Kala Jl. Meurandeh Kota Langsa, Provinsi Aceh, 24411, Indonesia \\ Email: moelmaulana1@gmail.com
}

\begin{abstract}
This article discuss about thematic study of hadith (mawdū' $\bar{\imath})$ methodologically.Mawdū' $\bar{\imath}$ method is collect hadith related to the topic or purpose.Thematic approach can be understood through content and purpose ofa hadith by studying relatedto it and see each correlation in order to obtain a full understanding on it. There are some steps in studying hadith thematic. study starts from the determination of themes or issues which will be discussed, collecting hadith related to the theme, categorization hadith, i'tibār whole sanad hadith, sanad research related to their personality and intellectual capacity of the narrators, study on matan related to proof whether 'illat (disability) and syā $\dot{z}$ (irregularities), an assessment of the themes that contain a similar meaning, comparison commentary tradition, completing discussions with the hadith or verse support, preparation of research results, and to be closed with a conclusion
\end{abstract}

Keywords: Mawdī' '̄, Thematics, Method

\begin{abstract}
Abstrak
Artikel ini membahas tentang kajian hadis tematik (mawdī'ì) secara metodologis. Metode mawdī' 'i adalah mengumpulkan hadis-hadis yang terkait dengan satu topik atau satu tujuan. Pendekatan tematik dalam pemahaman hadis adalah memahami maksud yang terkandung di dalam hadis dengan cara mempelajari hadis-hadis lain yang terkait dalam topik pembahasan yang sama dan memperhatikan korelasi masing-masingnya sehingga diperoleh pemahaman yang utuh. Langkah-langkah kajian hadis tematik dimulai dari penentuan tema atau masalah yang akan dibahas, pengumpulan hadis-hadis yang terkait dalam satu tema, kategorisasi hadis, i'tibār seluruh sanad hadis, penelitian sanad berupa kepribadian dan kapasitas intelektual perawi, penelitian matan berupa pembuktian ada tidaknya 'illah (kecacatan) dan syā̇ (kejanggalan), kajian atas tema-tema yang mengandung arti serupa, perbandingan syarah hadis, melengkapi pembahasan dengan hadis atau ayat pendukung, penyusunan hasil penelitian, dan diakhiri dengan penarikan kesimpulan.
\end{abstract}

Kata Kunci: Mawd̄̄'

\section{Pendahuluan}

Eksistensi hadis sebagai sumber otoritatif kedua setelah Alquran menempati posisi sentral dalam studi Islam. Otoritas hadis yang bersumber dari Nabi Muhammad saw. mendapat pengakuan dan legitimasi ilahiah. Beliau merupakan manifestasi Alquran yang bersifat praktis.
Antara keduanya; Alquran dan Hadis Nabi dalam beberapa literatur, dinilai berasal dari sumber yang sama. Perbedaan keduanya hanya pada bentuk dan tingkat otentisitasnya, bukan pada substansinya. Alquran dinyatakan sebagai wahyu matlū sementara Hadis Nabi dinyatakan sebagai wahyu gayr matlū. 
Terintegrasinya hadis Nabi pada wilayah ilahiyah, telah memposisikannya sebagai acuan bagi setiap muslim untuk mengabsahkan setiap prilakunya di berbagai komunitas di setiap zaman sebagai upaya untuk mendapatkan gelar sebagai muslimkäffah, bukan munkir alsunnah (hadis), dan penerus kerahmatan. Kehadiran hadis Nabi di setiap zaman dari peradaban manusia dituntut betul-betul mampu menjawab setiap permasalahan umat sebagai konsekuensi dialektis antara perkembangan zaman disatu sisi yang lain. Dan bukan sebaliknya, hadis menjadi penghalang dari setiap kemajuan peradaban manusia, dengan menghakiminya sebagai bidah ḍlālah, sumber per-pecahan, kejumudan, dan kemunduran.

Usaha di atas bukannya tanpa kendala. Mengingat proses takwīn al-hadīs terjadi ribuan tahun yang silam dengan tahapan dari setiap tahapan terajut dalam satu jalilnan proses yang multi-kompleks. Jika dewasa ini, hadis Nabi dapat dengan mudahnya dilacak dalam berbagai kitab mu'tabarah, kutub al-sittah, maka tidak serta merta usaha tersebut menjadi final, banyak dimensi lain yang penting untuk dipahami. Pada sisi lain, wajah studi hadis dalam sejarah panjang ilmu hadis lebih didominasi oleh isnad critique dengan menjadikan interprestasi tekstual-legalistik sebagian porosnya dalam kukungan paradigma teologis menyebabkan hadis kehilangan dan terputus dari konteks historisnya. Sehingga studi keislaman lalu hadir dalam paket-paket produk ulama abad pertengahan yang saling terpisah dan cenderung diidealisasikan sebagai produk yang final dan menempatkan Islam pada posisi terbelakang.

Based on that reality, berbagai kalangan menempatkan hadis sebagai objek kajian ilmu-ilmu modern sekalipun selama ini ilmu hadis dinilai sudah matang dan bahkan Baḥr al-Dīn al-Zarkasȳ̄ pernah memposisikan ilmu hadis sebagai ilmu yang telah matang dan terbakar. Hal menujukkan pengembangan ilmu tentang hadis Nabi menjadi suatu keniscayaan. Dalam kerangka inilah, maka salah satu hal yang menjadi perhatian penulis adalah bagaimana melakukan metode tematik pengkajian hadis Nabi, yang dirincikan dalam: Apa pengertian Metode Tematik?, Bagaimana langkah-langkah kajian hadis secara metode tematik?, dan Bagaimana contoh kajian hadis tematik?

\section{Definisi Studi Hadis Tematik (Mawḍ $\left.\bar{u}^{`} \bar{\imath}\right)$}

Secara bahasa kata maw dari kata موضوع yang merupakan isim $m a f^{\prime} \bar{u} l$ dari kata wada'a yang artinya masalah atau pokok permasalahan. ${ }^{1}$ Secara etimologi, kata maw $\operatorname{la}_{\bar{u}} \bar{\imath}$ yang terdiri dari

\footnotetext{
${ }^{1}$ Ahmad Warson Munawwir, al-Munawwir Kamus Arab-Indonesia (Surabaya: Pustaka Progressif, 1997), 1565.
} 
huruf gerarti meletakkan sesuatu atau merendah-kannya, sehingga kata maw $\bar{u}_{\bar{u}}{ }^{\prime} \mathrm{l}$ merupakan lawan kata dari al$r a f^{\prime} u$ (mengangkat). ${ }^{2}$ Mustafa Muslim berkata bahwa yang dimaksud mawḍ̄' ‘ adalah meletakkan sesuatu pada suatu tempat. Maka, yang dimaksud dengan metode maw $\bar{u}_{\bar{u}}{ }^{\prime} \bar{l}$ adalah mengumpulkan ayat-ayat yang bertebaran dalam Alquran atau hadis-hadis yang bertebaran dalam kitab-kitab hadis yang terkait dengan topik tertentu atau tujuan tertentu kemudian disusun sesuai dengan sebab-sebab munculnya dan pemahamannya dengan penjelasan, pengkajian dan penafsiran dalam masalah tertentu tersebut.

Menurut al-Farmawī sebagaimana dikutip oleh Maizuddin dalam bukunya Metodologi Pemahaman Hadis, disebutkan bahwa metode mawdī 'i $\bar{l}$ adalah mengumpulkan hadis-hadis yang terkait dengan satu topik atau satu tujuan kemudian disusun sesuai dengan asbāb alwurūd dan pemahamannya yang disertai dengan penjelasan, peng-ungkapan dan penafsiran tentang masalah tertentu. Dalam kaitannya dengan pemahaman hadis, pendekatan tematik (mawdī 'î) adalah memahami makna dan menangkap maksud yang terkandung di dalam hadis dengan cara mempelajari hadis-hadis lain yang

\footnotetext{
${ }^{2}$ Abū al-Husain Ahmad ibn Fahris ibn Zakariya, Mu 'jam Maqāyis al-Lugah, juz 2 (Beirūt: Dār al-Fikr, tth.), 218.
}

terkait dalam tema pembicaraan yang sama dan memperhatikan korelasi masingmasingnya sehingga didapatkan pemahaman yang utuh. ${ }^{3}$ Sedangkan Arifuddin Ahmad mengatakan bahwa metode maw $\bar{u}_{\bar{u}}{ }^{\imath} \mathrm{l}$ adalah pensyarahan atau pengkajian hadis berdasarkan tema yang dipermasalahkan, baik menyangkut aspek ontologisnya maupun aspek epistemologis dan aksiologisnya saja atau salah satu sub dari salah satu aspeknya. ${ }^{4}$ Metode mawḍ̄ 'ì sebagai salah salah satu metode tidak hanya berlaku dalam pemahaman Alquran melainkan juga dalam pemahaman hadis. Istilah metode tematik dalam pengkajian hadis Nabi merupakan terjemah darialmanhaj al-mawd̄̄ 'š fì syarh al-ḥadis. Selain metode tematik, dikenal sebelumnya dalam metode taḥlīlī dan metode muqāran.

Metode taḥlīlī mengandung pengertian pensyarahan atau pengkajian hadis secara rinci dari berbagai aspek tinjauan berdasarkan struktur matan sebuah hadis atau urutan matan hadis dari suatu kitab hadis secara runtut. $^{5}$ Pengkajian seperti ini, antara lain dilakukan oleh Ibnu Ḥajar al-'Asqalānī di dalam kitabnya Fatḥ

\footnotetext{
${ }^{3}$ Maizuddin, Metodologi Pemahaman Hadis (Padang: Hayfa Press, 2008), 13.

${ }^{4}$ Arifuddin Ahmad, Metode Tematik dalam Pengkajian Hadis (Makassar: Rapat Senat Luar Biasa UIN Alauddin Makassar), 4.

${ }^{5}$ Abd. Muim Salim, "Metodologi Tafsir: sebuah Rekonstruksi Epistemologi; Memantapka Keberadaan Ilmu Tafsir sebagai Disiplin Ilmu" dalam Orasi Pengukuhan Guru Besar (Makassar: Berkah Utami, 28 April 1999), 30.
} 
al-Bārī 'alā Syarḥ Șaḥị̣ al-Bukhārī. Sedangkan metode muqāran mengandung pengertian pensyarahan dan pengkajian hadis dengan membandingkan matan hadis yang beragam atau dengan menghubungkan dengan ayat-ayat Alquran dan atau membandingkan pendapat para ulama tentang kandungan satu hadis. Pengkajian seperti ini, antara lain dilakukan oleh alȘan'ānī di dalam kitabnya, Subul al-Salām: Syarh Bulūg al-Marām min Jamī‘ Adillah al-Ahkām. Hanya saja dalam metode maw $\bar{u}^{\prime}{ }^{\prime} \bar{l}$ ini dalam proses pemahaman kasus atau tema tertentu melibatkan semua hadis yang setema atau berhubungan dengan hadis. Kemudian penyelesaian ikhtilāf hadis sesuai dengan namanya, hanya pada kasus-kasus yang memperlihatkannya perbedaan makna hadis.

Sementara metode hadis mawḍ $\bar{u} \mathfrak{l}$ lebih luas lagi, mencakup semua kasus yang tidak terlihat adanya ikhtilāf di dalamnya ini dilakukan untuk menemukan makna substansial dari setiap kasus hadis yang dibahas dan dianalisis. Jadi metode maw d̦ $\bar{u}^{\prime} \bar{l}$ hadis yaitu suatu metode menghimpun hadis-hadis sahih yang topik pembahasannya sama. Dengan demikian, hal-hal yang syubhat dapat dijelaskan dengan hal-hal yang muhkam. Hal-hal yang muțlaq dapat di batasi dengan hal yang muqayyad (terikat) dan hal-hal yang bermakna umum dapat ditafsirkan oleh halhal yang bermakna khusus, sehingga makna yang dimaksud oleh subjek tersebut menjadi jelas dan tidak bertentangan.

Sejauh ini metode tematik dalam bidang tafsir telah mendapat respons yang cukup ramai di kalangan ahli tafsir untuk memahami isi kandungan Alquran, namun tidak terjadi di bidang hadis. Pesatnya perkembangan di bidang tafsir memacu mufassirūn untuk melakukan eksplorasi metodologi, di antaranya metode tematik, seperti yang dilakukan 'Abbās Maḥmūd al-'Aqqād, Fazlur Rahman, Toshihiko Izutzu, Quraish Shihab, Harifudin Cawidu dan sebagainya. Di kajian bidang Ulumul Hadis, ulama hadis berusaha merumuskan epistemologi ilm ma 'ānī al-ḥadīs yang boleh diartikan dengan ilmu tentang pemahaman hadis, namun ilmu ini belum banyak dikembangkan secara signifikan, sehingga belum bisa ditemukan rumusan metodologi yang mapan dalam aplikasinya. Akibatnya, pemahaman hadis Nabi cenderung masih bersifat general tanpa melihat struktur hadis. Artinya semua hadis dipahami sama, apakah itu riwāyah bi al-lafz atau riwāyah bi al-ma' $n \bar{a}$, begitu juga apakah hadis itu muțlaq atau muqayyad.

Hal ini disebabkan barangkali kompleksnya wilayah kajian 'ulūm alhadīis-sanad dan matan kalaupun ada yang berusaha melakukan pemahaman secara tematik, belum mencapai level yang memuaskan, karena yang muncul adalah 
baru pemahaman tekstual, parsial dan sporadis, tanpa melihat konteks kesejarahan (historis), ${ }^{6}$ geografis dan sosio-kultural, dan aspek lainnya misalnya kapasitas Nabi, setting antropologis, ${ }^{7}$ bahkan politis. ${ }^{8}$ Maka, sudah barang tentu pemahaman semacam ini tidak membuahkan hasil yang memuaskan yang bisa diacu secara keilmuan. Belum lagi pertimbanganpertimbangan kategorik hadis berdasar pada lokal, temporal (insidental) atau universal, termasuk kategori hadis tentang akidah, ibadah, atau muamalah.

Meskipun demikian, para ahli hadis berusaha keras melakukan klasifikasi dan sebagian kategorisasi, spesifikasi dan tematisasi, tetapi belum terlihat rumusan

\footnotetext{
${ }^{6}$ Historis, apakah dijadikan sebagai alat analisis ataupun sebagai pisau analisis. Dengan sejarah dapat membantu kita untuk memahami atau melakukan tarjih suatu hadis yang dimaknai.

${ }^{7}$ Sebagaimana yang pernah ditawarkan Said Agil Husein Al-Munawwar "Kemungkinan Pendekatan Historis dan Antropologis" dalam Yunahar Ilyas (ed.), Pengembangan Pemikiran terhadap Hadis (Yogyakarta: LPPI UMY, 1996), 155.

${ }^{8}$ Mengingat pada masa sahabat suasana politis sangat mewarnai pada saat hadis itu muncul, dengan melihat konsistensi dan tidaknya periwayatan hadis. Itulah sebabnya, para rawi hadis (rijal al-hadis) sangat perlu dilihat latar belakang politis. Rujukan kepada kitab-kitab sejarah Islam klasik sangat diperlukan dalam hal ini. Karena historiografi Islam dapat membantu secara serius dalam melakukan analisas secara kritis, apalagi dalam suatu hadis terdapat kata yang mubham, mujmal, muthlaq, muqayyad, 'am dan khash, musykil, termasuk juga nasikh dan mansukh. Belum lagi latar kesejarahan suatu peristiwa yang dinisbatkan kepada Nabi yang dikategorikan sunnah (as-Sunnah qabla at-Tadwin). Lihat Jalaluddin Rakhmat "Pemahaman Hadis: Perspektif Historis" dalam Ilyas (ed.), Pengembangan, 144.
}

metodologis dan kerangka kerjanya. Sehingga masih terkesan masih umum dan sedang menuju ke arah metode tematik. Sebagaimana yang telah dilakukan oleh Imam al-Syāfi'‘̄, yang mencoba mengkompilasi matan hadis semakna maupun yang kontradiktif (ta'ārud) untuk dilakukan kompromi, para penyusun Kutub al-Sittah, dengan model klasifikasi dan spesifikasi tema, juga kitab Bulūg alMarām dengan tampilan hadis yang bertema hukum. Begitu juga yang dilakukan Majdī ibn Manșūr ibn Sayyid alSyurī yang melakukan takhrīj secara spesifik terhadap hadis-hadis dalam Majmū ' al-Fatāwā li al-Imām Taqū al-Din Ibn Taymiyah. ${ }^{9}$ Mungkin yang lebih concern belakangan muncul Muhammad al-Gazālī, Yūsuf al-Qarạ̣āwī, dan Syuhudi Ismail. ${ }^{10}$

\section{Langkah-Langkah Studi Hadis Tematik}

Langkah-langkah pengkajian hadis dengan metode tematik ini antara lain dapat dilakukan dengan:

a. Menentukan tema atau masalah yang akan dibahas

b. Menghimpun atau mengumpulkan hadis-hadis yang terkait dalam satu tema, baik secara lafal maupun secara

${ }^{9}$ Berjudul al-Hawi fì Takhrīj Ahadis Majmū ‘ al-Fatāwā (Beirūt: Dār al-Kutub al-'Ilmiyyah, $1415 \mathrm{H} / 1995 \mathrm{M})$. Secara sistematis dan alfabetis memaparkan data hadis secara lengkap menurut kerangka metodologi takhrīj hadis.

${ }^{10}$ Suryadi dalam Jurnal Esensia, Fak. Ushuluddin, Vol. 3 No. 1 Januari 2002, 53. 
makna melalui ke-giatan takhrijj alhadīis.

c. Melakukan kategorisasi berdasarkan kandungan hadis dengan memperhatikan kemungkinan perbedaan peristiwa $w u r \bar{d} d$-nya hadis (tanawwu') dan perbedaan periwayatan hadis.

d. Melakukan kegiatan i'tibār dengan melengkapi seluruh sanad.

e. Melakukan penelitian sanad yang meliputi penelitian kualitas pribadi perawi, kapasitas intelektualnya dan metode periwayatan yang digunakan.

f. Melakukan penelitian matan yang meliputi kemungkinan adanya 'illat (cacat) dan syāż (kejanggalan).

g. Mempelajari tema-tema yang mengandung arti serupa

h. Membandingkan berbagai syarah hadis

i. Melengkapi pembahasan dengan hadis-hadis atau ayat-ayat pendukung

j. Menyusun hasil penelitian menurut kerangka besar konsep

k. Menarik suatu kesimpulan dengan menggunakan dasar argumentasi ilmiah. $^{11}$

Secara sepintas pemaknaan hadis dengan model tematik terkesan nampak sederhana, tetapi jika yang diinginkan hasil

\footnotetext{
${ }^{11}$ Muhammad Yusuf, Metode \& Aplikasi Pemaknaan Hadis (Yogyakarta: Sukses Offset, 2008), 27-29.
}

yang memadai sudah barang tentu diperlukan keseriusan, sehingga tidak semudah yang dikesankan, karena melibatkan sejumlah elemen pendukung yang memperkokoh kajian ini. Sehingga diharapkan dapat ditangkap makna yang holistik dari sebuah tema tertentu. Memang disadari, kajian ini menjadi sulit, jika seluruh langkah dan prosedur berikut ini dipenuhi secara konsisten dan lengkap. Paling tidak, tawaran model ini sedikit banyak mampu mengantarkan kita ke arah pemahaman yang lebih makro dan luas. Sehingga kandungan dalam hadis Nabi saw. didapatkan pemahaman yang lebih bermakna. Adapun prosedur kerja yang dapat dilakukan sebagai berikut.

Pertama yang harus ditempuh adalah menentukan tema tertentu sesuai keinginan, misalnya tema tentang iman, kepemimpinan, ilmu, etika pakaian, etika pergaulan, etika bisnis, dosa besar, tandatanda kiamat dan sebagainya. Kemudian menghimpun seluruh hadis-hadis yang sahih dan atau setidak-tidaknya hasan (senada/sejalan, tidak sejalan, tampak kontradiktif (ta'ārud// tanāquḍ), melalui prosedur takhrīj al-ḥadīs, dengan melakukan i'tibārāt, mutābi' 'ât dan syawāhid. ${ }^{12}$ Setelah berhasil menghimpun hadis-hadis setema, maka harus dilakukan tahqīq al-ḥadīs (prosedur verifikasi dan

\footnotetext{
${ }^{12}$ M. Syuhudi Ismail, Metodologi Penelitian Hadis Nabi (Jakarta: Bulan Bintang, 1986), 111.
} 
validasi), sehingga dapat diketahui kualitas sanad dan matannya. ${ }^{13}$ Karena, hadis yang memenuhi kualifikasi saja yang layak untuk dimaknai.

Agar dapat diketahui historisitas suatu hadis, maka pencarian asbāb alwurūd, ${ }^{14}$ menjadi signifikan dapat memperjelas sebab-sebab yang melatarbelakangi munculnya sebuah hadis tersebut, tentu saja yang dipilih telah memenuhi kualifikasi sanad dan rawi-nya berdasarkan teori-teori dalam studi ilmu-ilmu hadis. Langkah berikutnya adalah melakukan identifikasi teks (matan) hadis dari aspek kebahasaan (linguistik), terutama kata yang mutasyābih (dibawa ke yang muhkkam), muṭlaq (mengaitkan ke yang muqayyad) atau makna konotasi ke denotasi, dan 'àmm (menafsirkan ke yang $k h \bar{a} s$ ) artinya dari makro ke mikro, musykil (menuju ke makna yang șarīh), haqūqī dan majazī, juga makna yang garīb ke makna waḍịh, dan sebagianya. ${ }^{15}$

\footnotetext{
${ }^{13}$ Diprioritaskan hadis-hadis yang berkualitas shahih (yang berkaitan dengan aqidah dan ibadah), atau paling tidak hasan (jika berkenaan dengan akhlak dan faḍ̂̄'il al-a 'māl).

${ }^{14}$ Yakni peristiwa yang melatarbelakangi munculnya sebuah hadis, merupakan kausa. Terutama hadis-hadis tentang hukum, karena perubahan sebab, situasi dan 'illat, kecuali hadishadis tentang eskatologis dan aqidah yang tidak membutuhkan asbab al-wurud al-hadis. Lihat: Muh. Zuhri, Telaah Matan Hadis sebuah Tawaran Metodologis (Yogyakarta: Lesfi, 2003), 62.

${ }^{15}$ Kaidah kebahasaan ini dikaji dalam Ilmu Balaghah, mengingat kapasitas nabi sebagai orang yang fașịh dan balīg dalam berbahasa Arab. Ulama' muta'akhkhirūn menganjurkan agar bahasa produk 15 abad yang lalu dapat dipahami secara pas oleh generasi sekarang diperlukan pengetahuan tentang
}

Sehingga dapat diharapkan dapat membantu proses penarikan ide utama/pokok (main idea) yang akan dimaknai. Ide pokok dalam sebuah hadis tidak cukup hanya melihat bab-bab, tematema, judul-judul yang ada dalam kitabkitab hadis. Karena dimungkinkan ide pokok itu tidak tunggal, meskipun kadangkadang terlihat ide sekunder (secondary ide). Dari sinilah sebenarnya kesatuan ide terbentuk untuk meng-giring pada suatu konsep tertentu. Langkah berikutnya adalah meneliti dalalah (variable-variabel) yang akan memberikan batasan sebelum dilakukan pemaknaan secara utuh.

Secara ijmak kaum muslimin, bahwa hadis Nabi berfungsi menjadi bayān, tafsir dan tafṣ̄ll bahkan berfungsi sebagai taqyīd dan takhșịs terhadap suatu persoalan tertentu, sehingga teks (ayat-ayat) Alquran secara proporsional harus dilibatkan, ${ }^{16}$ jika peneliti tidak menemukan secara tekstual (literal) bisa dicari ideal moralnya atau kandungan maknawi (spirit). Bukankah segala tindakan Nabi yang menyangkut, ucapan (statement), tindakan (action), sikap (attitude), dan keputusan

social setting ketika itu.

${ }^{16}$ Untuk mengetahui ayat mana yang ditindaklanjuti oleh hadis. Mengingat hadis tidak boleh ada kontradiksi dengan Alquran, jika ada kontradiksi maka bisa jadi periwayatnyalah yang keliru atau bi al-wahn, dan harus didahulukan Alquran dan wajib ma'mūl bih. Lihat Said Agil alMunawwar, "Kemungkinan Pendekatan Historis dan Antropologis" dalam Ilyas (ed.), Pengembangan, 167. 
(judgment) Nabi adalah mencerminkan keseluruhan gagasan etika Alquran (akhlak Alquran), yang memang mendapat otorisasi dari Allah Swt.

Kemudian, peneliti dapat menempuh pemaknaan yang holistik-komprehensif secara interdisipliner dengan melihat, menyapa dan mengkorelasikan teori-teori ilmu pengetahuan yang relevan, ${ }^{17}$ sehingga terjadi dialog keilmuan yang harmonis dengan saling melengkapi dan memperkokoh satu sama lainnya. Dengan melalui langkah ini dimungkinkan pengembangan dan "pengembaraan" makna lebih luas dan lebih jauh untuk tujuan kontekstualisasi. ${ }^{18}$ Sehingga hadis Nabi, tidak kering dari elan vital-nya, sejak kemunculannya hingga kini. Meskipun tidak bisa dipungkiri, bahwa hadis memiliki dimensi temporal, insidental, lokal maupun universal, yang harus menjadi pertimbangan berikutnya.

Analisis terhadap muatan matan hadis, yang mungkin tepat adalah analisis historis dengan berbagai pertimbangan dan alasan akademik, antara lain:

Pertama, pada masa sahabat, hadis-

\footnotetext{
${ }^{17}$ Untuk memperoleh pemahaman yang utuh untuk menguak informasi tentang konfigurasi yang menyelimuti munculnya hadis. Lihat Zuhri, Telaah, 89. Langkah ini dalam rangka melihat konteks historis maupun antropologis pada saat hadis itu muncul (Asbāb al-Wurūd al-Hadīis).

${ }^{18}$ Paradigma ini menyangkut wilayah falsafi, metode, strategi dan substansi, sehingga dipertimbangkan wilayah mana yang paling mendekati dan paling memungkinkan; atau paling tidak dapat membantu sebagai perspektif keilmuan.
}

hadis yang disampaikan sangat diwarnai oleh situasi politik. Karena dengan itu, kita dapat menjelaskan posisi yang tepat antara konsistensi dan inkonsistensi dalam periwayatan hadis. Sejarah dapat membantu untuk mengkrititisi, menerima atau menolak (tajrīh dan ta'dīl).

Kedua, untuk memahami hadis perlu mengetahui latar belakang politis para rijāl hadis, tak terkecuali para sahabat Nabi Saw sebagaimana yang dikaji buku-buku rijāl al-ḥadīis, seperti al-Ișābah, al-Isti 'āb, Mīzān al-I 'tidāl, Tahìīb al-Tahżìb, Usud alGābah dan sebagainya yang dilengkapi dengan literatur klasik (historiografi) Islam agar didapatkan kajian kritis.

Ketiga, keberpihakan para rawi hadis seringkali mengurangi atau paling tidak mengaburklan matan hadis.

Keempat, karena kita terlanjur menyimpulkan sunnah dari hadis, maka latar kesejaharahan dari suatu peristiwa dan momentum menjadi sangat penting. ${ }^{19}$ Analisis historis ini dipandang urgen dalam studi hadis terutama metode ma'ān̄ alhadīs, dalam rangka untuk mengetahui konteks di masa lalu (kesejarahan) pada saat hadis berdialektika dengan ruang sosial untuk dijadikan cermin pandang konteks kekinian bagi pencarian ide dan gagasan dari munculnya sebuah peristiwa pada saat

\footnotetext{
${ }^{19}$ Jalaluddin Rakhmat "Pemahaman Hadis: Perspektif Historis" dalam Jurnal Al-Hikmah, Bandung, 17, Vol. VII, Tahun 1996, 24.
} 
Muhammad saw. bertindak sebagai utusan Allah (Rasūlullāh) untuk misi kemanusiaan. Bagi Fazlur Rahman, hadis dipahami sebagai produk evolutif dari konsep sunnah (tradition) sejak awal dipahami sebagai konsep perilaku, hukum tingkah laku, hukum moral yang bersifat normatif, praktik aktual (Barat), tingkah laku yang merupakan teladan, konsep pengayoman, terma perilaku (behavioral) karena dalam praktiknya tidak ada dua buah kasus yang benar-benar sama latar belakang situasional (asbāb al-wurūd)-nya secara moral, psikologis dan material, maka sunnah harus dapat diinterpretasikan dan diadaptasikan.

\section{Contoh Studi Hadis Metode Tematik}

Dalam dunia bisnis, Nabi Saw. pernah bersabda tentang larangan menimbun harta dagangan dengan merumuskan kode etik dan hukum dagang yang adil dan humanis. Setidaknya ada tiga buah hadis yang dapat dipaparkan, yaitu:

1. Hadis pertama, diriwayatkan oleh Ahmad bersifat informatif:

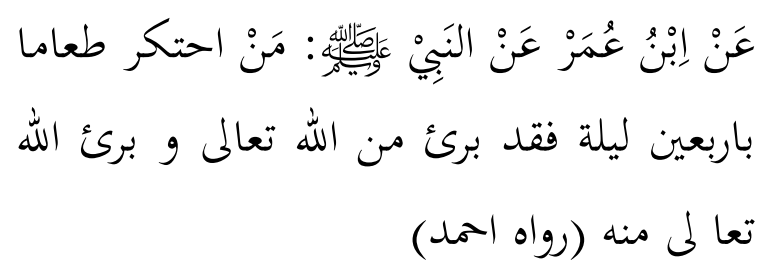

"Dari Ibnu 'Umar, dari Nabi Saw, bahwa Beliau bersabda: Barangsiapa menimbun bahan pangan selama 40 malam, maka dia telah mengacuhkan Allah Ta'ala dan Allah benar-benar telah tidak mengacuhkannya." (H.R. Aḥmad)

2. Hadis kedua, diriwayatkan oleh Muslim, isinya bersifat pernyataan tegas, menimbun makanan itu suatu tindakan yang salah:

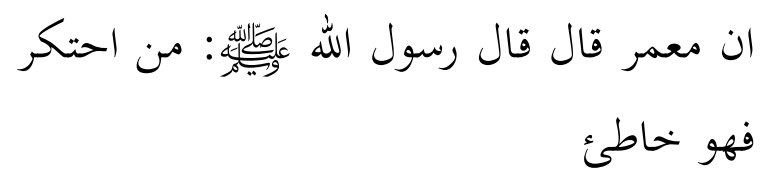

"Sesungguhnya Ma'mar berkata, telah bersabda Rasulullah alaihi wa sallam: Barangsiapa yang menimbun (sesuatu) berarti telah melakukan tindakan salah" (H.R. Muslim)

3. Hadis ketiga, diriwayatkan oleh Ibn Mājah dan al-Dārimī yang isinya bersifat hukuman bagi penimbun berupa kutukan:

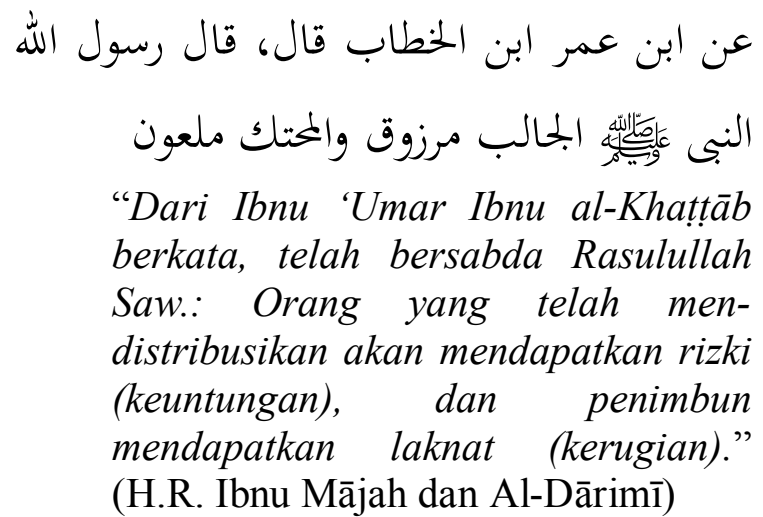

Dari hadis di atas bila dikaji menurut metode tematik, maka aplikasinya sebagai berikut:

Langkah ke-1: Menentukan tema. Secara jelas temanya adalah penimbunan (al-Ihtikār), dengan penyebutan kata kunci, yaitu: "حتكر" (penimbunan) disebutkan dua 
kali dan "المحتكر" (penimbun) disebutkan sekali.

Langkah ke-2 dan ke-3: Bila dilihat dari segi sanad, bahwa hadis nomor pertama dan kedua diriwayatkan oleh beberapa orang rawi melalui jalur Imam Muslim dan Abū Dāwud dan sanadnya sahih, ada yang mengatakan sanadnya hasan melalui jalur lain, sehingga derajatnya menjadi șaḥ̄h li gayrihi, karena adanya mutābi' yang berpredikat sahih. Hadis pertama, meskipun sanadnya hasan, tetapi sejalan dengan hadis kedua. ${ }^{20}$ Sedangkan hadis ketiga diriwayatkan oleh Ibn Mājah dan al-Dārimī dengan kualitas sanad hasan. Ketiga hadis tersebut tidak ada kontradiksi dan diungkapkan dengan bahasa yang jelas, bahkan saling melengkapi dan memperkuat, sehingga memenuhi syarat untuk dimaknai.

Langkah ke-4: melacak asbāb alwurūd.

Hadis tersebut ditemukan asbāb alwurūd, bahwa di zaman Nabi Saw, ada dua sahabat (rawi hadis) saling tuding melakukan perbuatan penimbunan (ihtikār), Said tertuduh sebagai pelaku penimbunan (muhtakir), tetapi Said mengelak, bahkan menuduh balik Ma'mar-lah yang melakukan praktik penimbunan. Sehingga muncul perdebatan cukup sengit di antara

${ }^{20}$ Zuhri, Telaah, 79. Dalam Muslim hadis nomer 3012, Abu Daud: 2990, Ibn Majah: 2145, Ahmad: 15198, 15201, 25987 dan al-Tirmidzi: 1188. berdua.

Langkah ke-5: Analisa linguistik, yang paling mungkin dilihat adalah kalimat: Abu Yusuf memberi arti Ihtikar yaitu "Setiap yang diperlukan kepentingan dam menahannya”. Kalimat ini adalah 'am, tanpa ada kepastian subyek pelakunya laki-laki atau perempuan, beragama Islam ataupun tidak, tanpa ada kategori kelas pengusaha, apakah kecil, menengah atau konglomerat. Kata kedua, طعام (makanan) adalah kata muthlaq, tanpa disebutkan secara spesifik (muqayyad) jenis makanan/barang apa yang ditimbun, bisa beras, jagung, gandum, minyak atau jenis bahan/barang yang lain, juga tanpa ada batasan (limit) berapa besar dan jumlahnya. Secara tekstual, penimbunan tersebut mengindikasikan secara jelas jika dilakukan selama 40 malam.

Langkah ke-6: Ada beberapa konsep ekonomis yang dapat ditangkap antara lain tentang distribusi, pasar, supply and demand, stabilitas ekonomi, dan sebagainya. Ide pokok (ihtikar) terkait erat dengan konsep ekonomi yang menyangkut masalah distribusi, bukan masalah berapa waktu penimbunan. Dalam ekonomi, dikenal dengan istilah "hukum pasar" yang menganut hukum supply and demand (persediaan dan permintaan). Dalam prinsip ini, bila terjadi ketidaklancaran dalam sistem distribusi (suatu barang), secara 
konvensi yang dilihat adalah masalah distribusi, apakah ada keseimbangan antara persediaan (supply) dengan permintaan (demand). Karena ketidakberimbangan antara keduanya, bisa dipastikan akan memunculkan masalah pasar. Jika tidak, maka dicari faktor-faktor yang mempengaruhinya, sehingga menjadi jelas persoalannya. Faktor-faktor terdekat anatara lain menyangkut tentang a) produksi dan distribusi b) keadilan ekonomi, c) konsep harga, d) konsep stabilitas dan ketahanan pangan, e) kesejahteraan sosial, f) politik ekonomi, dan mungkin juga lain yang dipandang relevan.

Langkah ke-7: Pemaknaan terhadap kandungan hadis dengan cara melihat variabel dan indikatornya.

Variabel terlihat dari hadis pertama adalah berupa kata kunci (keyword) طعام, indikatornya adalah 40 hari. Secara tekstual dipahami, menimbun pangan selama kurang dari 40 hari diperbolehkan (hadis I) dan perbuatan ihtikar merupakan perbuatan yang salah (hadis II) dan orang yang melancarkan distribusi dagangan (bahan makan) akan diberi rizki sedang bagi penimbun adalah terkutuk (hadis III). Menurut ar-Ramli dalam kamusnya, Ihtikar berarti: Menimbun sama artinya perbuatan aniaya dan buruk pergaulan dan perbuatan, atau dapat diartikan sebagai احتباس: (menahan/menyandra).
Langkah ke-8: Pemaknaan yang holistik-komprehensif (integratif-interkonektif) Persoalan pokok dari hadis-hadis tersebut adalah isu ekonomi, lebih khusus persoalan penimbunan makanan. Jika dilihat wilayah kajiannya termasuk masā'il al-fiqhiyyah bidang mu'āmalah māliyah. Maka untuk menentukan dan menjelaskan konsep yang ada, tidak cukup hanya berkutat hanya pada wilayah teks secara sempit tanpa didekati dengan teoriteori ekonomi yang terkait erat dengan tema.

Secara fitrah, manusia hidup selalu berusaha untuk memenuhi hajat hidup agar dapat bertahan hidup secara wajar. Makanan merupakan kebutuhan manusia paling asasi (basic need) berupa bahan pangan untuk keperluan sehari-hari, sesuai dengan konteks geografi dan kebiasaan suatu daerah/wilayah atau negara tertentu. Jika bahan pangan ditimbun oleh seseorang atau kelompok atas nama individu atau perusahaan pasti berakibat pada kelangkaan. Kecuali yang melakukan penimbunan (ihtikār) adalah pemerintah untuk maksud-maksud yang positif, di zaman Nabi saw adalah pihak Baitul Mal, itupun untuk maksud mengendalikan distribusi dan harga.

Variabel lain, menurut hukum pasar, jika terjadi kelangkaan apapun jenis barangnya, maka secara otomatis sistem distribusi akan terganggu yang akan 
mempengaruhi harga pasar. Sedangkan indikatornya, masyarakat merasa kesempitan dan kesulitan karena terbatasnya barang apalagi berupa bahan pangan. Jika dibiarkan lambat laun pada gilirannya menimbulkan goncangan ekonomi yang berimplikasi pada terganggunya stabilitas ekonomi, tindak kriminal meningkat, kamtibmas terusik, maraknya pelanggaran hukum. Jika hal ini terjadi, sangat mungkin terjadinya konflik, baik secara vertikal maupun horisontal.

Ketidaklancaran sistem distribusi biasanya dilakukan oleh para spekulan dan pelaku monopoli, yang mengambil kesempatan dalam kesempitan yang berujung pada keuntungan pada segelintir orang dan kelompok kecil tertentu. Dalam konteks Indonesia, pada 10 tahun terakhir telah dihebohkan berbagai krisis dari berbagai dimensi, mulai dari moneter, kepercayaan, ekonomi dan politik. Yang paling berpengaruh ketika rakyat Indonesia menghadapi kelangkaan beras dan BBM. Sekarang basic need orang telah berkembang yang menyangkut berbagai jenis barang pokok kebutuhan masyarakat, seperti gula, BBM, gas, minyak goreng, tepung dan susu.

Akibatnya harga dari waktu ke waktu mengalami fluktuasi kenaikan yang signifikan, sehingga memberatkan masyarakat. Bahkan terakhir krisis energi (listrik) yang telah mengancam di beberapa daerah, terutama di Jawa. Sementara pemerintah merasakan berat untuk mengatasinya, paling-paling menempuh langkah impor terutama sembako jenis beras dan gula. Kemudian ditindaklanjuti dengan operasi pasar, seperti kasus kelangkaan minyak tanah, beras, gas elpiji, premium, dan yang terakhir minyak goreng yang hingga kini belum pulih. Asumsi kapitalistiknya, mekanisme harga tidak dapat berbuat banyak untuk mengerem keserakahan nafsu dan konsumsi foya-foya sekuler, tanpa memperhatikan sistem harga dan kehendak social, karena sistem kapitalisme kata M. Umer Chapra, ${ }^{21}$ meletakkan beban yang jauh lebih besar pada pundak mekanisme harga daripada kemampuan daya pikulnya.

Jika disederhanakan pemahaman kita, sebuah konsep dalam sebuah bahasa (hadis) tersebut ternyata memiliki makna implikasi yang luas (efek domino) dalam kehidupan, terutama menimbulkan ketidakseimbangan (disequilibrium), tidak hanya pada sektor ekonomi, tetapi juga sosial, hukum, dan sebagainya.

Langkah ke-9: pelacakan ayat-ayat yang terkait dengan perdagangan, apakah itu sarīh ataupun ghairu sarīh yang membicarakan: prinsip-prinsip ekonomi, etika-moral, dan aspek teologis, antara lain:

\footnotetext{
${ }^{21}$ M. Umer Chapra, Islam dan Tantangan Ekonomi, terj. Ikhwan Abidin Basri (Jakarta: Gema Insani Press, 2000), 37.
} 


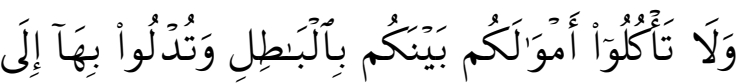

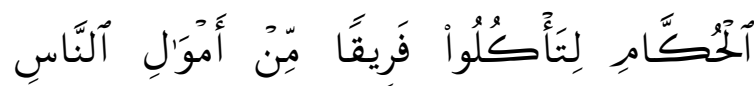

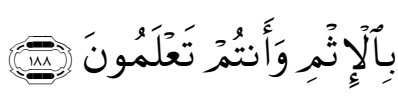

"Dan janganlah sebahagian kamu memakan harta sebahagian yang lain di antara kamu dengan jalan yang bathil dan (janganlah) kamu membawa (urusan) harta itu kepada hakim, supaya kamu dapat memakan sebahagian daripada harta benda orang lain itu dengan (jalan berbuat) dosa, Padahal kamu mengetahui. (Q.S. Al-Baqarah: 188)

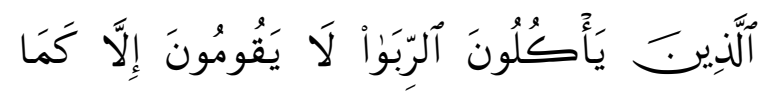

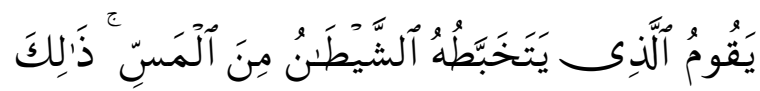

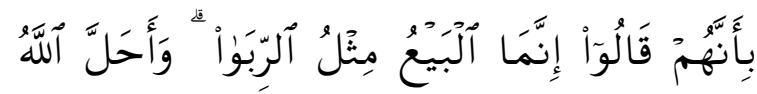

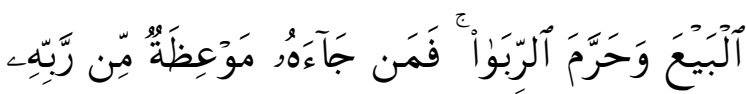

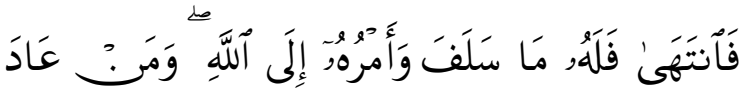

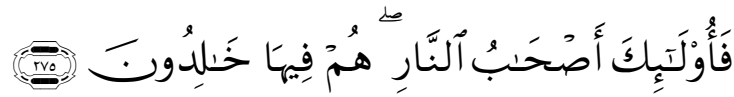
"Orang-orang yang Makan (mengambil) riba tidak dapat berdiri melainkan seperti berdirinya orang yang kemasukan syaitan lantaran (tekanan) penyakit gila. Keadaan mereka yang demikian itu, adalah disebabkan mereka berkata (berpendapat), Sesungguhnya jual beli itu sama dengan riba, Padahal Allah telah menghalalkan jual beli dan mengharamkan riba. orangorang yang telah sampai kepadanya larangan dari Tuhannya, lalu terus berhenti (dari mengambil riba), Maka baginya apa yang telah diambilnya dahulu (sebelum datang larangan); dan urusannya (terserah) kepada Allah. orang yang kembali (mengambil riba), Maka orang itu adalah penghuni-penghuni neraka; mereka kekal di dalamnya." (Q.S. AlBaqarah: 275)

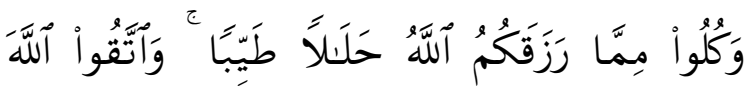

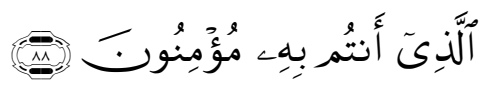

"Dan makanlah makanan yang halal lagi baik dari apa yang Allah telah rezekikan kepadamu, dan bertakwalah kepada Allah yang kamu beriman kepada-Nya." (Q.S. AlMaidah: 88)

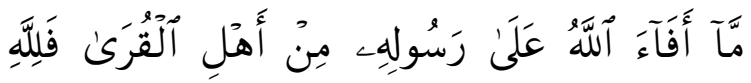

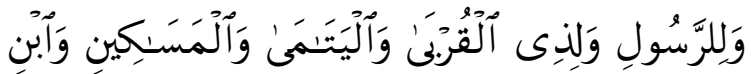

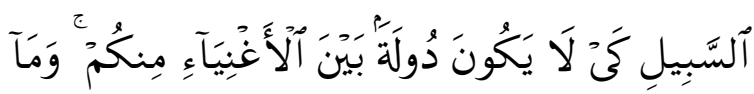

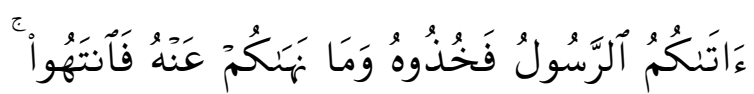

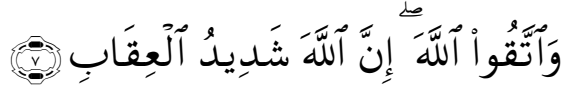

"Apa saja harta rampasan (fai-i) yang diberikan Allah kepada RasulNya (dari harta benda) yang berasal dari penduduk kota-kota Maka adalah untuk Allah, untuk rasul, kaum kerabat, anak-anak yatim, orang-orang miskin dan orang-orang yang dalam perjalanan, supaya harta itu jangan beredar di antara orang-orang Kaya saja di antara kamu. apa yang diberikan Rasul kepadamu, Maka terimalah. dan apa yang dilarangnya bagimu, Maka tinggalkanlah. dan bertakwalah kepada Allah. Sesungguhnya Allah Amat keras hukumannya." (Q.S. AlHasyr: 7).

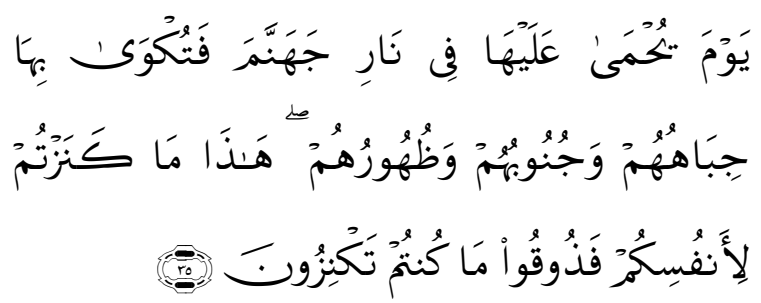


"Pada hari dipanaskan emas perak itu dalam neraka Jahannam, lalu dibakar dengannya dahi mereka, lambung dan punggung mereka (lalu dikatakan) kepada mereka: "Inilah harta bendamu yang kamu simpan untuk dirimu sendiri, Maka rasakanlah sekarang (akibat dari) apa yang kamu simpan itu." (Q.S. AlTaubah: 35)

Langkah ke-10: Pemaknaan secara kontekstual. Dalam Islam, mungkin juga dalam agama-agama yang lain memiliki prinsip ajaran bahwa manusia hidup itu harus saling tolong-menolong, memberi kemudahan-kemudahan (profesional) dan tidak saling membuat kesempitan dan kesengsaraan orang lain. Humanisme ini mengandung doktrin yang paling mendasar bahwa kepemilikan itu bersifat nisbi, meskipun tak dibatasi kuantitasnya selama kewajiban terhadap kepemilikan itu dipenuhi dan di dalamnya mengandung hak orang lain. Maka setiap perilaku ekonomi harus memperhatikan etik-moral, artinya tindakan ekonomi tidak sebebas-bebasnya melakukan apa saja menurut keinginan dan interes subyeknya, tanpa memperhatikan kepentingan masyarakat luas.

Mengenai tempo 40 hari yang disebutkan dalam hadis itu, merupakan jangka waktu yang rasional dan relevan untuk mengukur gejolak pasar. Logikanya, barang apa saja yang ditimbun dan berakibat pada gejolak ekonomi (pasar) meskipun penimbunannya hanya pendek (kurang dari 40 hari) tetap dilarang. Jika barang itu yang ditimbun berupa kebutuhan dasar/pokok mayoritas orang, maka dapat dikategorikan sabotase ekonomi yang mengarah pada tindakan subversif. Di Negara kita Indonesia memegang prinsip bahwa kepentingan hajat orang banyak lebih dahulukan daripada kepentingan minoritas orang. Meskipun realitasnya tidak demikian, sehingga sering diterpa badai ekonomi yang bertubi-tubi.

Di kalangan ahli fiqh dalam mensikapi hal ini beragam pandangan, seperti Abu Yusuf melihat keumuman teks hadis menyatakan bahwa setiap tindakan ihtikār dilarang tidak terbatas bahan pangan, apalagi bahan pangan tersebut sangat dibutuhkan masyarakat umum. Karena penimbunan akan menimbulkan bahaya yang merata (darar), maka hukumnya haram yang dapat dianalogikan (qiyās) sebagai perbuatan dhalim, karena yang untung hanya pihak yang kuat (kapitalis), sedangkan pihak konsumen menjadi berat dan kesulitan. Ihtikār, termasuk usaha spekulatif mengandung arti membeli suatu komoditi dengan maksud akan menjualnya dengan harga yang lebih tinggi, hal ini mengakibatkan kenaikan harga. karena berkurangnya barang dengan cara buatan. Kenaikan harga buatan ini oleh Islam tidak dibenarkan, bahkan 
dikutuk (mal 'ūn). ${ }^{22}$

Bahkan bila dimaknai lebih jauh, penimbunan hanya salah satu contoh tindakan ekonomi yang salah, karena dalam kenyataannya banyak tindakan lain yang berbeda tetapi juga menimbulkan gejolak ekonomi, misalnya eksport yang irasional (tanpa kendali), deposito uang dalam jumlah yang besar di bank-bank internasional (luar negeri) dalam praktik money loundry, spekulasi, pasar gelap (black market), monopoli-oligopoli (dalam produkdi dan peranan), monosopnioligosopni (bidang pembelian), eksplorasi tanpa batas, eksploitasi sumberdaya alam (misalnya: illegal logging), yang menjurus mencari keuntungan dengan segala cara (profiteering) dan penyalahgunaan kebebasan pasar. $^{23}$

Bagi Abu Hanifah, larangan ihtikar hanya diperuntukkan bagi bahan pangan pokok (sembako) yang selalu diperlukan masyarakat umum/luas. Berbeda dengan muridnya, Abu Yusuf dengan melihat keumuman teks Hadis (matan), larangan ihtikar itu berlaku umum untuk barang selain bahan pangan, termasuk emas, perak, uang, pakaian dengan alasan bahwa tindakan itu menimbulkan kebencian dan betul-betul berdampak negatif (haqīqah al-

${ }^{22}$ M. Abdul Manan, Teori dan Praktek Ekonomi Islam, terj. M. Nastangin (Yogyakarta: Dana Bhakti Prima Yasam 1997), 156.

${ }^{23}$ A.A. Islahi, Konsepsi Ekonomi Ibnu Taimiyah, terj. H. Anshari Thayib (Surabaya: Bina Ilmu, 1997), 297. darar). Prinsip ini dipegang baik oleh etika ekonomi Islam bahwa madlarat yang direncanakan secara sadar dan dilakukan oleh seseorang atau kelompok kecil untuk tujuan dimaksud atau tidak, tetap harus dilenyapkan tanpa harus mempertimbangkan niat (motif) yang melatarbelakanginya. Meskipun tetap diakui bahwa menghilangkan madlarat sama sekali dalam kehidupan manusia tidak mungkin.

Dalam konteks ini, keterlibatan pemerintah dalam pasar tidak hanya pada saat tertentu atau temporal saja. Bagi sistem ekonomi Islam, ia sebagai muhtasib yang menempati posisi sebagai fungsi negara, yakni sebagai perencana, pengawas, produsen dan sekaligus sebagai konsumen. Di negara Indonesia, fungsi ini ada di Bappenas dan bidang terkait lainnya seperti Ekuin, Perdagangan, Ekowasbang dan Bulog, maka seharusnya mereka inheren ada di pasar bersama-sama dengan unitunit ekonomik lainnya berdasarkan landasan yang tetap dan stabil. Oleh karena itu, keterlibatan pemerintah dalam pasar berfungsi sebagai supervisor (supervisi) dan controller (pengontrol). Dalam hal ini ada dua corak kontrol terhadap mekanisme pasar, pertama dimaksudkan uintuk meningkatkan pemenuhan tujuan-tujuan negara secara efisien dan corak kontrol kedua yaitu Hisbah yang fungsinya adalah memelihara agar aturan-aturan 
main (role of game) bisa selalu didukung. Hisbah, adalah sebuah sistem yang berwenang untuk melakukan pengecekan langsung (direct control), kendali mutu, standarisasi, kerapian dan kesopanan terhadap masyarakat, termasuk memiliki kewenangan untuk melarang praktik kartel dan monopoli. ${ }^{24}$

Menurut kebijakan ekonomi (khususnya Negara Islam), meminimisasi kesenjangan distributif Islam diserap dari spirit Alquran dan Sunnah yang berkaitan dengan perilaku konsumtif seperti adanya larangan bermewah-mewah, berlebihlebihan, larangan peredaran dan pemusatan (konsentrasi) harta hanya di kalangan sejumlah kecil orang tertentu, karena Islam mengedepankan aspek kemasyarakatan (social-minded). Maka basis utama distribusi dalam Islam adalah prinsip kesamaan harga diri (sawāsiyyah), pemerataan (equity) dan persaudaraan (ukhuwwah), ${ }^{25}$ sehingga kesejahteraan individu dan masyarakat luas (individual and social welfare) dapat terjamin, sebagai pemenuhan rasa keadilan, termasuk keadilan dalam bidang produksi, konsumsi dan distribusi.

Langkah ke-11 (akhir): pengambilan

\footnotetext{
${ }^{24}$ Monzer Kahf, Ekonomi Islam (Telaah Analitik terhadap Fungsi Sistem Ekonomi Islam), terj, Machnun Husein (Yogyakarta: Pustaka Pelajar, 1995), 68-69.

${ }^{25}$ Amin Akhtar dalam Ainur R. Sophiaan, Etika Ekonomi Politik (Surabaya: Risalah Gusti, 1997), 87, 101.
}

kesimpulan. Dari uraian di atas, bisa ditarik kesimbulan relevan, bahwa semua tindakan ekonomi yang didasarkan atas kepentingan sektoral-eksklusif (individu maupun kelompok tertentu), sebagai tindakan penyalahgunaan kebebasan pasar, karena hak-hak publik (public rights) akan terganggu, terutama dalam pemenuhan kebutuhan dan pada glilirannya akan menimbulkan instabilitas di beberapa sektor kehidupan yang menjurus kepada perilaku dhalim. Sesungguhynya rizki dari Allah dilarang untuk dimonopoli dengan cara dan dalih apapun, termasuk di dalamnya adalah ihtikar, sejak abad pertengahan umat Islam menentangnya, yang dikategorikan tindakan dosa, karena menimbulkan dampak pada harga yang tidak adil dan tidak jujur, yang hal itu tidak dikehendaki yurisprudensi Islam sejak awal, sebab dalam sistem ekonomi termasuk ekonomi Islam menghendaki harga yang ekuivalen (setara) atau ṡaman al-miśl.

Untuk mensikapi hal itu, maka pemerintah (Ulil Amri) melalui institusi hisbah sebagai pengontrol dan pengawas berkewajiban dan bertanggung jawab mengendalikan sistem produksi dan distribusi barang, terutama bahan pangan pokok (basic need) dan kebutuhan primer lainnya, dengan tidak memberi ruang dan kesempatan bagi pelakunya menerapkan sistem bebas (laissez faire), tapi harus mengedepankan sistem terkendali yang 
berbasis etika dan moral yang melekat dan demi kesejahteraan rakyat. Hadis di atas bila dilihat dari perspektif filsafat ilmu, secara ontologis, kebenaran ajaran yang dikandung tidak cukup untuk diyakini pada level iman saja, sedangkan pada dataran epistemologis institusi ekonomi (hisbah) berperan dalam mengatur dan mengendalikan mekanisme pasar yang menyangkut produksi dan distribusi, sehingga tindakan pengawasan, regulasi dan pencegahan (aksiologis) terhadap perilaku pasar bisa dikendalikan, termasuk praktik ihtikār. Bila dilihat dari kandungan hadis, muatan substansinya berskala makrouniversal yang tidak dibatasi oleh dimensi ruang geografi dan waktu, karenanya mengandung tuntutan aktual syar'iyyah yang harus ditaati oleh seluruh pelaku ekonomi, khususnya para praktisi/pelaku ekonomi Islam.

\section{Kesimpulan}

Studi hadis maud̄ ${ }^{\prime} \bar{l}$ adalah mengumpulkan hadis-hadis yang terkait dengan satu topik atau satu tujuan kemudian disusun sesuai dengan $a s b a \bar{b} a l$ wurūd dan pemahamannya yang disertai dengan penjelasan, pengungkapan dan penafsiran tentang masalah tertentu. Dalam kaitannya dengan pemahaman hadis

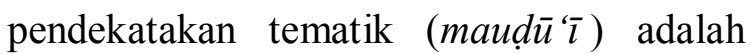
memahami makna dan menangkap maksud yang terkandung di dalam hadis dengan cara mempelajari hadis-hadis lain yang terkait dalam tema pembicaraan yang sama dan memperhatikan korelasi masingmasingnya sehingga didapatkan pemahaman yang utuh.

$$
\text { Langkah-langkah studi hadis }
$$

tematik dapat disimpulkan sebagai berikut: Menentukan tema dibahas, menghimpun atau mengumpulkan hadis-hadis yang terkait, melakukan kategorisasi berdasarkan kandungan hadis, melakukan kegiatan i'tibar, melakukan penelitian sanad, dan melakukan penelitian matan.

Penelitian matan hadis meliputi kemungkinan adanya illat (cacat) dan syaż (kejanggalan), mempelajari tematema yang mengandung arti serupa, membandingkan berbagai syarah hadis, melengkapi pembahasan dengan hadishadis atau ayat-ayat pendukung, menyusun hasil penelitian menurut kerangka besar konsep, dan menarik suatu kesimpulan dengan menggunakan dasar argumentasi ilmiah. 


\section{Daftar Pustaka}

Aḥmad, Abū al-Ḥusain. Mu 'jam Maqāyis al-Lugah. Beirūt: Dār al-Fikr, t.th.

Ahmad, Arifuddin. Metode Tematik dalam Pengkajian Hadis. Makassar: Rapat Senat Luar Biasa UIN Alauddin Makassar.

Akhtar, Amin. Etika Ekonomi Politik. Surabaya: Risalah Gusti, 1997.

Chapra, M. Umer. Islam dan Tantangan Ekonomi. Terj. Ikhwan Abidin Basri. Jakarta: Gema Insani Press, 2000.

Islahi, A.A. Konsepsi Ekonomi Ibnu Taimiyah. Terj. H. Anshari Thayib Surabaya: Bina Ilmu, 1997.

Ismail, M. Syuhudi. Metodologi Penelitian Hadis Nabi. Jakarta: Bulan Bintang, 1986.

Kahf, Monzer. Ekonomi Islam: Telaah Analitik terhadap Fungsi Sistem Ekonomi Islam. Terj, Machnun Husein, Yogyakarta: Pustaka Pelajar, 1995.

Maizuddin. Metodologi Pemahaman Hadis. Padang: Hayfa Press, 2008.

Manan, M. Abdul. Teori dan Praktek Ekonomi Islam. Terj. M. Nastangin, Yogyakarta: Dana Bhakti Prima Yasam 1997.

al-Munawwar, Said Agil Husein. "Kemungkinan Pendekatan Historis dan Antropologis" dalam Yunahar Ilyas, Pengembangan Pemikiran terhadap Hadis. Yogyakarta: LPPI UMY, 1996.

Munawwir, Ahmad Warson. Al-Munawwir Kamus Arab-Indonesia. Surabaya: Pustaka Progressif, 1997.

Rakhmat, Jalaluddin. "Pemahaman Hadis: Perspektif Historis" dalam Jurnal AlHikmah, Bandung, 17, Vol. VII, Tahun 1996.

Salim, Abd. Muim. "Metodologi Tafsir: sebuah Rekonstruksi Epistemologi; Memantapkan Keberadaan Ilmu Tafsir sebagai Disiplin Ilmu" dalam Orasi pengukuhan Guru Besar, Makassar: Berkah Utami, 28 April 1999.

Surya. Jurnal Esensia, Fak. Ushuluddin. Vol. 3 No. 1 Januari 2002.

Yusuf, Muhammad. Metode \& Aplikasi Pemaknaan Hadis. Yogyakarta: Sukses Offset, 2008.

Zuhri, Muh. Telaah Matan Hadis sebuah Tawaran Metodologis. Yogyakarta: Lesfi, 2003. 